\title{
Frequency of troponin elevations in patients with COVID-19 and clinical course in these patients
}

\author{
๑Kadem Arslan, @Süleyman Baş \\ Sancaktepe Sehit Prof. Dr. İlhan Varank Training and Research Hospital, Department of Internal Medicine, İstanbul, Turkey
}

Cite this article as: Arslan K, Baş S. Frequency of troponin elevations in patients with COVID-19 and clinical course in these patients. Anatolian Curr Med J 2022; 4(1); 95-102.

\begin{abstract}
Aim: We aimed to determine the frequency of troponin elevations in COVID-19 patients and to investigate the role of troponin in demonstrating the prognosis of COVID-19 by examining the clinical course of theese patients.

Material and Method: Patients diagnosed with COVID-19 disease were included in the study. Patient files were analyzed retrospectively through the hospital information management system.Patients with high troponin levels were identified and comparisons were made with patients with normal troponin levels.

Results: 1468 patients were included in the study.Troponin level was found to be high in $6.7 \%$ of the patients. The presence of pneumonia on thorax CT rate,hospitalization rate,ICU admission rate,intubation rate was significantly higher in patients with high troponin levels. The mortality rate was $2.1 \%$ in the whole group.The mortality rate was significantly higher in the patients with high troponin levels. Total length of hospital and ICU stay were significantly higher in patients with high troponin levels. There was a significant positive correlation between the troponin levels of the patients at admission and the total length of hospital stay and length of ICU stay. $49.5 \%$ of COVID-19 patients had another comorbid disease.Hypertension was the most common comorbid disease. The rate of troponin elevation and troponin levels were significantly higher in patients with other comorbid diseases.
\end{abstract}

Conclusion: It has been found that high troponin levels in COVID-19 patients may be associated with a poor clinical prognosis. Troponin can be used as a predictor of prognosis with more comprehensive studies and long-term follw-up results in the future.

Keywords: COVID-19, SARS-CoV-2, troponin, cardiac biomarkers, prognosis

\section{INTRODUCTION}

Cardiac troponins are highly sensitive and specific biomarkers of myocardial diseases. In acute coronary syndrome, elevated troponin levels are important in terms of both prognosis and treatment guidance. For this reason, troponin level measurements are frequently used in the diagnosis of acute coronary syndrome in emergency departments and intensive care units. After acute myocardial injury, blood levels increase within 2-4 hours, reach a peak in 24 hours, and then blood troponin levels remain high for about 2-3 weeks. In the guidelines, the increase in cardiac troponins is accepted as the basic diagnostic criterion in the definition of acute myocardial infarction $(1,2)$.

Although troponin elevation is an important indicator of coronary ischemia, it should not be forgotten that it may increase in other clinical conditions and should not always be interpreted in favor of coronary ischemia.
It is known that troponin levels can be measured high in patients who are admitted to hospital for any reason $(3,4)$. Renal failure, myocarditis, pulmonary embolism, arrhythmia, cerebrovascular events, malignancy, trauma, severe infection, toxicity etc in such cases, high troponin levels can be detected without acute coronary syndrome.

The causative agent of coronavirus disease 2019 (COVID-19) is severe acute respiratory syndrome coronavirus 2 (SARS-CoV-2) $(5,6)$. SARS-CoV-2 is an enveloped RNA virus (4). COVID-19 has similar signs, symptoms and effects as severe acute respiratory syndrome (SARS) and Middle East respiratory syndrome (MERS). The agents of SARS, MERS and COVID-19 belong to the Coronaviridae family and the Coronavirinae subfamily $(7,8)$. COVID-19 was first diagnosed in Wuhan, China, in December 2019, but then spread all over the world. 
COVID-19 has been declared a pandemic by the World Health Organization as of March 11, 2020. In humans, the main route of transmission of SARS CoV-2 is viruscarrying respiratory droplets (9). Generally, COVID-19 patients develop symptoms 5-7 days after exposure. Common symptoms are fever, sore throat, cough, myalgia, headache, dyspnea, nausea, diarrhea.

SARS-CoV-2 enters the cell by attaching to the angiotensin converting enzyme 2 (ACE2) receptor. The infection process begins with the binding of the viral envelope $S$ protein of SARS CoV-2 to the ACE2 receptor in the cell membrane. The ACE2 receptor is found especially in the lungs, endothelium, heart, kidneys, brain and intestines $(10,11)$. Therefore, all these organs can be the target of the virus and complications may occur in these organs.

As the ACE2 receptor is also expressed in cardiac myocytes and endothelium, they are potential targets of SARS-CoV-2. SARS CoV-2 can infect myocytes and endothelial cells directly, or damage these organs by causing thrombotic processes. Likewise, cytokine storms and activation of coagulation cascades caused by SARS Cov- 2 triggering inflammatory processes are also likely to cause pathological effects on the heart and endothelium. Pathological events such as hypoxia, systemic inflammation, sepsis, thromboembolic events, systemic adrenergic hyperstimulation that may occur in COVID-19 disease can also cause non-ischemic myocardial events and endothelial pathologies. While much is unclear about Sars-Cov-2, it is likely that involvement similar to past viral outbreaks will occur. Previous viral epidemics, including MERS-CoV and SARS, have also been associated with myocardial damage and troponin elevation by the same mechanisms $(12,13)$.

In COVID-19 disease, new markers are needed to show the prognosis of the disease. In this context, scientific studies are needed. Today, we do not have a proven marker that will enable us to take positive steps on clinical course and mortality by determining the risk of developing ischemic or non-ischemic cardiovascular events in COVID-19 disease. In this study, we planned to determine the frequency of troponin elevation in COVID-19 patients and to investigate the role of troponin test in demonstrating the prognosis of COVID-19 disease by examining the clinical course of the patient group with high troponin test.

\section{MATERIAL AND METHOD}

For this study, approval was obtained from Istanbul Sancaktepe Sehit Prof. Dr. İlhan Varank Training and Research Hospital Ethics Committee (Decision No: 2021/84, (Date: 29/01/2021). All human studies have been performed under the rules of 1964 Declaration of
Helsinki. Because the study was designed retrospectively, no written informed consent form was obtained from patients.

Patients diagnosed with COVID-19 between 01/04/2020 and 31/07/2020 were included in the study. Patients over 18 years old, with positive COVID-19 PCR test results, and patients with thorax computerised tomography (Thorax CT) and troponin test on admission were included in the study. Patients diagnosed with acute coronary syndrome or acute cerebrovascular disease as a result of consultations due to high troponin levels were excluded from the study. Patients younger than 18 years old, had pregnancy, diagnosed with malignancy or renal failure were excluded from the study. Patient files were analyzed retrospectively through the hospital information management system. The demographic characteristics, medical history, COVID-19 PCR test results, blood test results, thorax ct reports, hospitalization status, intensive care admission status, length of hospitalization stay, intubation status and treatment results of the patients were examined. Troponin I test was performed on the patients at admission. The reference range was given as $0-28.9 \mathrm{pg} / \mathrm{ml}$ for males and $0-13.8 \mathrm{pg} / \mathrm{ml}$ for females. Patients with high troponin levels were identified and comparisons were made with patients with normal troponin levels.

\section{Statistical Analysis}

Statistical analysis was made with the data obtained. IBM Corporation SPSS (Statistical Package for Social Sciences), version 23.0, New York, US was used for statistical analyses. While evaluating the study data, the suitability of the parameters to the normal distribution was evaluated by Kolmogorov-Smirnov and Shapiro Wilks tests. Descriptive statistical methods including percentage and mean \pm standard deviation $( \pm S D)$ or median (interquartile range [IQR] were used to provide the basic features of the data, according to the evaluation of distribution for normality. An independent sample t-test was used to analyze quantitative data. Differences in the values of the variables between the groups were evaluated by the Mann-Whitney $\mathrm{U}$ test. Chi-square test was used to analyze qualitative data. A value of $\mathrm{P}<0.05$ was considered to be statistically significant. Spearman Correlation test was performed to evaluate the relationship between troponin levels and length of hospitalization stay in hospitalized patients. Receiver Operating Characteristic (ROC) curve analysis was performed to determine the significant troponin level in prognosis in patients admitted to the intensive care unit and patients who died. As a result of the ROC curve analysis, the cut-off value of the troponin test and the sensitivity and specificity of this value were determined. The area under the ROC curve (AUC) value was calculated with a $95 \%$ confidence interval. 


\section{RESULTS}

A total of 1468 patients, 708 females (48.2\%), 760 males $(51.8 \%)$, were included in the study. The median age of the patients was found to be 50 [IQR: 38 -60] years (Table 1). $77 \%$ of females and $79.7 \%$ of males were hospitalized. $47.4 \%$ of the hospitalized patients were female and $52.6 \%$ were male. There was no significant difference in hospitalization rate according to gender (Table 1). The median age of the patients treated in the hospital was 54 [IQR: 43 - 63] years, and the median age of the patients treated at home was 38 [iIQR: 2848] years. Median age was significantly higher in hospitalized patients $(\mathrm{p}<0.001)$ (Table 1). Troponin level was found to be high in $6.7 \%$ of the patients. The average age of patients with high troponin levels was found to be $68.22 \pm 14.23$ years. Patients with high troponin levels were significantly older than patients with normal troponin levels $(\mathrm{p}<0.001)$ (Table 2). The troponin level was high in $8.2 \%$ of the females. In female patients, the rate of troponin elevation was found to be significantly higher than males $(\mathrm{p}<0.033)$ (Table 2). $96 \%$ of the patients with high troponin levels were treated in hospital. Troponin elevation was detected in $8.3 \%$ of the inpatients. Troponin elevation was detected in 4 of the patients treated at home. Hospitalization was significantly higher in patients with high troponin levels $(\mathrm{p}<0.001)$ (Table 1). The troponin levels of hospitalized patients were significantly higher than patients treated at home $(\mathrm{p}<0.001)($ Table 1$)$.

\begin{tabular}{|c|c|c|c|c|}
\hline & $\underset{(n=1468)}{\text { All }}$ & $\begin{array}{c}\text { Treated } \\
\text { at home } \\
(\mathrm{n}=317)\end{array}$ & $\begin{array}{l}\text { Hospitalized } \\
(\mathbf{n}=1151)\end{array}$ & $\mathbf{p}$ \\
\hline Age (year) & $\begin{array}{c}50 \\
{[38-60]^{\dagger}}\end{array}$ & $\begin{array}{c}38 \\
{[28-48]^{\dagger}}\end{array}$ & $\begin{array}{c}54 \\
{[43-63]^{\dagger}}\end{array}$ & $<0.001^{\mathrm{a}}$ \\
\hline Gender & & & & $0.199^{\mathrm{b}}$ \\
\hline Male & $760(51.8 \%)$ & $154(20.3 \%)$ & $606(79.7 \%)$ & \\
\hline Female & $708(48.2 \%)$ & $163(23 \%)$ & $545(77 \%)$ & \\
\hline $\begin{array}{l}\text { Patients with high } \\
\text { troponin level }\end{array}$ & $\begin{array}{c}99 \\
(6.7 \%)\end{array}$ & $\begin{array}{c}4 \\
(4 \%)\end{array}$ & $\begin{array}{c}95 \\
(96 \%)\end{array}$ & $<0.001^{\mathrm{b}}$ \\
\hline $\begin{array}{l}\text { Troponin Level } \\
\text { (pg/ml) }\end{array}$ & $\begin{array}{c}2.70 \\
{[1.50-5.20]^{\dagger}}\end{array}$ & $\begin{array}{c}1.60 \\
{[0.90-2.70]^{\dagger}}\end{array}$ & $\begin{array}{c}3.00 \\
{[1.70-6.20]^{\dagger}}\end{array}$ & $<0.001^{\mathrm{a}}$ \\
\hline
\end{tabular}

Pneumonia due to COVID-19 was found on thorax CT of $72.5 \%$ of all patients. $87.9 \%$ of the patients with elevated troponin level had pneumonia on thorax CT. The presence of pneumonia on thorax CT was found to be significantly higher in patients with elevated troponin levels $(\mathrm{p}<0.001)$ (Table 2). Table 2. Comparison of patients with high and normal troponin levels

\begin{tabular}{|c|c|c|c|c|c|}
\hline & & All patients $(n=1468)$ & $\begin{array}{l}\text { Patients with normal } \\
\text { troponin level }(n=1369)\end{array}$ & $\begin{array}{c}\text { Patients with high } \\
\text { troponin level }(n=99)\end{array}$ & $\mathbf{p}$ \\
\hline \multicolumn{2}{|l|}{ Age (year) } & $50[38-60] \dagger$ & $49[37-58] \dagger$ & $68.22 \pm 14.23^{\star}$ & $<0.001^{\mathrm{a}}$ \\
\hline Gender & $\begin{array}{l}\text { Male } \\
\text { Female }\end{array}$ & $\begin{array}{l}760(51.8 \%) \\
708(48.2 \%)\end{array}$ & $\begin{array}{l}719(94.6 \%) \\
650(91.8 \%)\end{array}$ & $\begin{array}{l}41(5.4 \%) \\
58(8.2 \%)\end{array}$ & $<0.033^{\mathrm{b}}$ \\
\hline Comorbid disease & $\begin{array}{l}\text { Yes } \\
\text { No }\end{array}$ & $\begin{array}{l}727(49.5 \%) \\
741(50.5 \%)\end{array}$ & $\begin{array}{l}643(88.4 \%) \\
726(98 \%)\end{array}$ & $\begin{array}{c}84(11.6 \%) \\
15(2 \%)\end{array}$ & $<0.001^{\mathrm{b}}$ \\
\hline Hypertension & $\begin{array}{l}\text { Yes } \\
\text { No }\end{array}$ & $\begin{array}{c}410(27.9 \%) \\
1058(72.1 \%)\end{array}$ & $\begin{array}{c}351(85.6 \%) \\
1018(96.2 \%)\end{array}$ & $\begin{array}{l}59(14.4 \%) \\
40(3.8 \%)\end{array}$ & $<0.001^{\mathrm{b}}$ \\
\hline Type 2 Diabetes & $\begin{array}{l}\text { Yes } \\
\text { No }\end{array}$ & $\begin{array}{c}286(19.5 \%) \\
1182(80.5 \%)\end{array}$ & $\begin{array}{c}252(88.1 \%) \\
1117(94.5 \%)\end{array}$ & $\begin{array}{c}34(11.9 \%) \\
65(5.5 \%)\end{array}$ & $<0.001^{\mathrm{b}}$ \\
\hline Hyperlipidemia & $\begin{array}{l}\text { Yes } \\
\text { No }\end{array}$ & $\begin{array}{c}141(9.6 \%) \\
1327(90.4 \%)\end{array}$ & $\begin{array}{c}118(83.7 \%) \\
1251(94.3 \%)\end{array}$ & $\begin{array}{l}23(16.3 \%) \\
76(5.7 \%)\end{array}$ & $<0.001^{\mathrm{b}}$ \\
\hline Asthma & $\begin{array}{l}\text { Yes } \\
\text { No }\end{array}$ & $\begin{array}{c}81(5.5 \%) \\
1387(94.5 \%)\end{array}$ & $\begin{array}{c}77(95.1 \%) \\
1292(93.2 \%)\end{array}$ & $\begin{array}{c}4(4.9 \%) \\
95(6.8 \%)\end{array}$ & $0.505^{\mathrm{b}}$ \\
\hline $\begin{array}{l}\text { Coronary artery } \\
\text { disease }\end{array}$ & $\begin{array}{l}\text { Yes } \\
\text { No }\end{array}$ & $\begin{array}{c}75(5.1 \%) \\
1393(94.9 \%)\end{array}$ & $\begin{array}{c}56(74.7 \%) \\
1313(94.3 \%)\end{array}$ & $\begin{array}{l}19(25.3 \%) \\
80(5.7 \%)\end{array}$ & $<0.001^{\mathrm{b}}$ \\
\hline Hospitalisation & $\begin{array}{l}\text { Yes } \\
\text { No }\end{array}$ & $\begin{array}{c}317(21.6 \%) \\
1151(78.4 \%)\end{array}$ & $\begin{array}{c}313(98.7 \%) \\
1056(91.7 \%)\end{array}$ & $\begin{array}{l}4(1.3 \%) \\
95(8.3 \%)\end{array}$ & $<0.001^{\mathrm{b}}$ \\
\hline $\begin{array}{l}\text { Pneominoa on } \\
\text { thorax ct }\end{array}$ & $\begin{array}{l}\text { Yes } \\
\text { No }\end{array}$ & $\begin{array}{c}1064(72.5 \%) \\
404(27.5 \%)\end{array}$ & $\begin{array}{c}977(91.8 \%) \\
392(97 \%)\end{array}$ & $\begin{array}{l}87(8.2 \%) \\
12(3 \%)\end{array}$ & $<0.001^{\mathrm{b}}$ \\
\hline Admitted to & $\begin{array}{l}\text { Ward } \\
\text { ICU }\end{array}$ & $\begin{array}{c}1082(73.7 \%) \\
69(4.7 \%)\end{array}$ & $\begin{array}{c}1012(93.5 \%) \\
44(63.8 \%)\end{array}$ & $\begin{array}{c}70(6.5 \%) \\
25(36.2 \%)\end{array}$ & $<0.001^{\mathrm{b}}$ \\
\hline Intubation & $\begin{array}{l}\text { Non-intubated } \\
\text { Intubated }\end{array}$ & $\begin{array}{c}29(2 \%) \\
40(2.7 \%)\end{array}$ & $\begin{array}{l}22(75.9 \%) \\
22(55 \%)\end{array}$ & $\begin{array}{l}7(24.1 \%) \\
18(45 \%)\end{array}$ & $0.075^{\mathrm{b}}$ \\
\hline Cliinical outcome & $\begin{array}{l}\text { Healed } \\
\text { Ex }\end{array}$ & $\begin{array}{c}1437(97.9 \%) \\
31(2.1 \%)\end{array}$ & $\begin{array}{c}1355(94.3 \%) \\
14(45.2 \%)\end{array}$ & $\begin{array}{l}82(5.7 \%) \\
17(54.8 \%)\end{array}$ & $<0.001^{\mathrm{b}}$ \\
\hline \multicolumn{2}{|c|}{ Length of stay in hospital (day) } & $7[6-10] \dagger$ & $7[6-9] \dagger$ & $11[7-17] \dagger$ & $<0.001^{\mathrm{a}}$ \\
\hline \multicolumn{2}{|c|}{ Length of stay iin ward (day) } & $7[5-9] \dagger$ & $7[5-8] \dagger$ & $7[6-11] \dagger$ & $0.013^{\mathrm{a}}$ \\
\hline \multicolumn{2}{|c|}{ Length of stay in ICU (day) } & $12[7.50-17] \dagger$ & $10.50[6.25-16] \dagger$ & $14[9-22.50] \dagger$ & $0.037^{\mathrm{a}}$ \\
\hline
\end{tabular}


The mean age of the patients admitted to the ICU was $62.07 \pm 16.21$ years (Table 2). Patients who were admitted to the ICU were significantly older $(\mathrm{p}<0.001)$ (Table 3 ). $29 \%$ of the patients were females and $71 \%$ were males admitted to the ICU (Table 3). The ICU admission rate was $8.1 \%$ in males and \%3.7 in females. The ICU admission rate was significantly higher in males $(\mathrm{p}=0.002)$ (Table 3). $26.3 \%$ of the patients with troponin elevation were admitted to the ICU. The ICU admission rate was significantly higher in patients with elevated troponin levels $(\mathrm{p}<0.001)$ (Table 3). Troponin levels of patients admitted to the ICU were found to be significantly higher $(\mathrm{p}<0.001)$ (Table 3). $36.2 \%$ of the patients admitted to ICU had high elevated levels.

\begin{tabular}{|c|c|c|c|c|}
\hline & $\begin{array}{c}\text { All } \\
\text { hospitalized } \\
\text { patients } \\
(\mathbf{n}=1151)\end{array}$ & $\begin{array}{c}\text { In Ward } \\
(\mathbf{n}=1082)\end{array}$ & $\begin{array}{l}\text { In ICU } \\
(\mathrm{n}=69)\end{array}$ & p \\
\hline Age (year) & $54[43-63] \dagger$ & $53[42-62] \dagger$ & $62.07 \pm 16.21^{*}$ & $<0.001^{a}$ \\
\hline Gender & & & & $0.002^{\mathrm{b}}$ \\
\hline Male & $606(52.6 \%)$ & $557(91.9 \%)$ & $49(8.1 \%)$ & \\
\hline Female & $545(47.4 \%)$ & $525(96.3 \%)$ & $20(3.7 \%)$ & \\
\hline $\begin{array}{l}\text { Patients with high } \\
\text { troponin level }\end{array}$ & $95(8.3 \%)$ & $70(73.7 \%)$ & $25(26.3 \%)$ & $<0.001^{\mathrm{b}}$ \\
\hline $\begin{array}{l}\text { Troponin Level } \\
\text { (pg/ml) }\end{array}$ & $\begin{array}{c}3.00 \\
{[1.70-6.20] \dagger}\end{array}$ & $\begin{array}{c}2.90 \\
{[1.70-5.60] \dagger}\end{array}$ & $\begin{array}{c}13.30 \\
{[6.50-48.45] \dagger}\end{array}$ & $<0.001^{\mathrm{a}}$ \\
\hline $\begin{array}{l}\text { a Mann-Whitney test } \\
\text { range [IQR]), }{ }^{\star} \text { Data a }\end{array}$ & $\begin{array}{l}\text { Chi-Square Test, } \\
\text { resented as mean }\end{array}$ & $\dagger$ Data are prese & $\begin{array}{l}\text { ted as median (inte } \\
\text { tion (SD) }\end{array}$ & erquarti \\
\hline
\end{tabular}

While the rate of females was $55 \%$ in intubated patients, the rate of males was $59.2 \%$. No statistically significant difference was found between the ages and genders of the intubated and non-intubated patients (Table 4). $72 \%$ of the patients with elevated troponin levels admitted to ICU were intubated. According to the troponin levels, no statistically significant difference was found in intubation rates (Table 4). The troponin levels of the intubated patients were significantly higher than patients who were not intubated $(p=0.0018)$ (Table 4).

\begin{tabular}{|c|c|c|c|c|}
\hline & $\underset{(v=69)}{\operatorname{In} \operatorname{ICU}_{(\mathrm{All})}}$ & $\begin{array}{c}\text { Non- } \\
\text { intubated } \\
(n=29)\end{array}$ & $\begin{array}{c}\text { Intubated } \\
(n=40)\end{array}$ & $\mathbf{p}$ \\
\hline Age (year) & $62.07 \pm 16.21^{*}$ & $58.62 \pm 14.12^{*}$ & $64.58 \pm 17.31^{*}$ & $+0.133^{\mathrm{a}}$ \\
\hline Gender & & & & $0.749^{b}$ \\
\hline Male & $49(71 \%)$ & $20(40.8 \%)$ & $29(59.2 \%)$ & \\
\hline Female & $20(29 \%)$ & $9(45 \%)$ & $11(55 \%)$ & \\
\hline $\begin{array}{l}\text { Patients with high } \\
\text { troponin level }\end{array}$ & $25(36.2 \%)$ & $7(28 \%)$ & $18(72 \%)$ & $0.075^{\mathrm{b}}$ \\
\hline $\begin{array}{l}\text { Troponin Level } \\
\text { (pg/ml) }\end{array}$ & $\begin{array}{c}13.30 \\
{[6.50-48.45]^{\dagger}}\end{array}$ & $\begin{array}{c}9.00 \\
{[4.35-17.50]^{\dagger}}\end{array}$ & $\begin{array}{c}16.45 \\
{[8.22-81.12]^{\dagger}}\end{array}$ & $0.018^{c}$ \\
\hline
\end{tabular}

The mortality rate in the whole patient group was found to be $2.1 \%$. Troponin levels was high in $54.8 \%$ of the patients who died. Mortality development was significantly higher in the patient group with elevated troponin levels $(\mathrm{p}<0.001)$ (Table 2).

The median length of hospital stay in the group with elevated troponin levels was 11 [IQR: 7 - 17] days, and the medianlength of ICU stay was 14 [IQR: 9 - 22.50] days. In the group with normal troponin levels, the median length of hospital stay was 7 [IQR: 5 - 9] days, and the median length of ICU stay was 12 [IQR: 7.50 17] days. Total length of hospital stay and ICU stay were significantly higher in patients with elevated troponin levels $(\mathrm{p}<0.001, \mathrm{p}=0.037)$ (Table 2). In the correlation analysis performed between troponin levels and the length of hospital stay, there was a significant positive correlation between the troponin levels of the patients at admission and the total length of hospital stay and length of ICU stay. The total length of hospital stay and length of ICU stay was significantly increased in patients with elevated troponin levels. It was determined that as the troponin levels of the patients at admission increased, the total length of hospital stay and the length of ICU stay increased (Table 5). The ROC curve was drawn to determine the effect level and cut off value of the troponin variable in COVID-19 patients admitted to ICU, the area under the curve was 0.821, and the standard error was found to be 0.028 . The area under the ROC curve was found to be statistically significant $(p<0.001)$. The cut off value for troponin was found to be 6.85 , and the sensitivity of this value is $75.4 \%$ and the specificity is $80 \%$ (Figure 1) (Table 6).

\begin{tabular}{|c|c|c|}
\hline & Correlation coefficient & $\mathbf{P}$ \\
\hline \multicolumn{3}{|l|}{ Spearman's Rho } \\
\hline Length of stay in hospital & 0,228 & $<0,001$ \\
\hline Length of stay iin ward & 0,165 & $<0,001$ \\
\hline Length of stay in ICU & 0,440 & 0,003 \\
\hline
\end{tabular}

\section{Table 6. ROC curve for the troponin variable of COVID-19} patients admitted to the ICU

\begin{tabular}{|ccccc|}
\hline $\begin{array}{c}\text { AUC (\%95 } \\
\text { confidence interval) }\end{array}$ & $\begin{array}{c}\text { Cutt- } \\
\text { off }\end{array}$ & $\mathbf{P}$ & $\begin{array}{c}\text { Sensitivity } \\
\mathbf{( \% )}\end{array}$ & $\begin{array}{c}\text { Specificity } \\
\text { (\%) }\end{array}$ \\
\hline $0,821(0,766-0,876)$ & 6,85 & $<0,001$ & 75,4 & 80 \\
\hline
\end{tabular}

In the ROC curve drawn for the troponin variable of the COVID-19 patients who died, the area under the curve is 0.896 and its standard error is 0.031 . The area under the ROC curve was found to be statistically significant $(p<0.001)$. The cut off value for troponin was found to be 7.55 . The sensitivity of this value is $84.6 \%$, and the specificity is $83.9 \%$ (Table 7) (Figure 2). 


\begin{tabular}{|c|c|c|c|c|}
\hline $\begin{array}{c}\text { AUC (\%95 } \\
\text { confidence interval) }\end{array}$ & $\begin{array}{l}\text { Cutt- } \\
\text { Off }\end{array}$ & $\mathbf{P}$ & $\begin{array}{c}\text { Sensitivity } \\
(\%)\end{array}$ & $\begin{array}{c}\text { Specificity } \\
(\%)\end{array}$ \\
\hline $0,896(0,835-0,957)$ & 7.55 & $<0.001$ & 84.6 & 83.9 \\
\hline
\end{tabular}

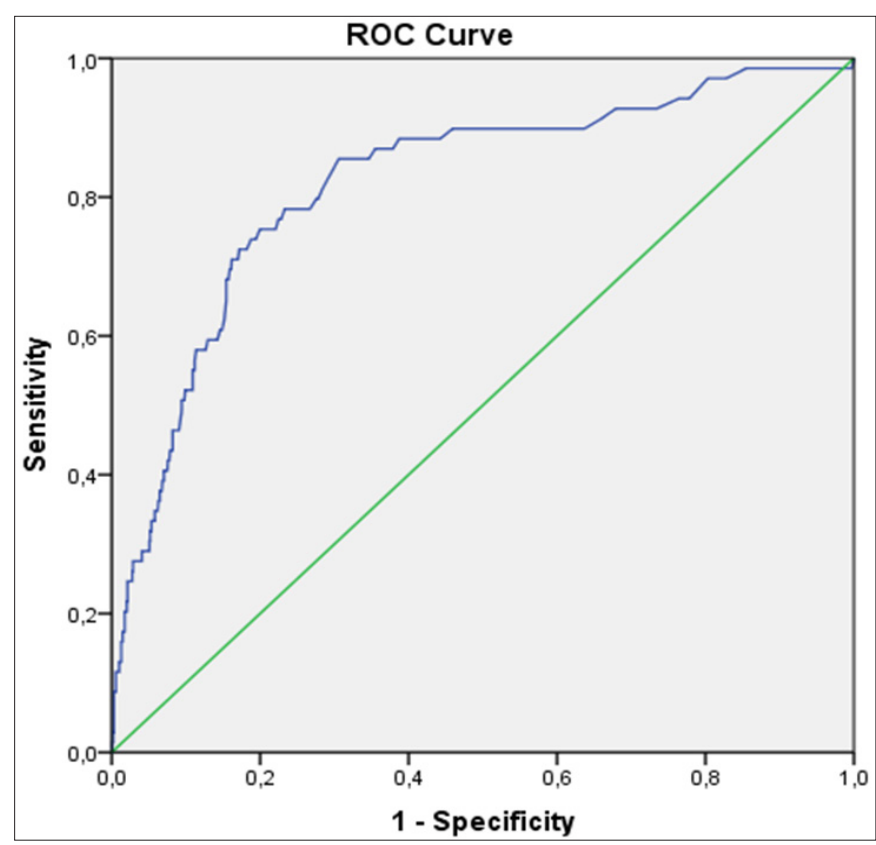

Figure 1. ROC curve for the troponin variable of the patients in ICU

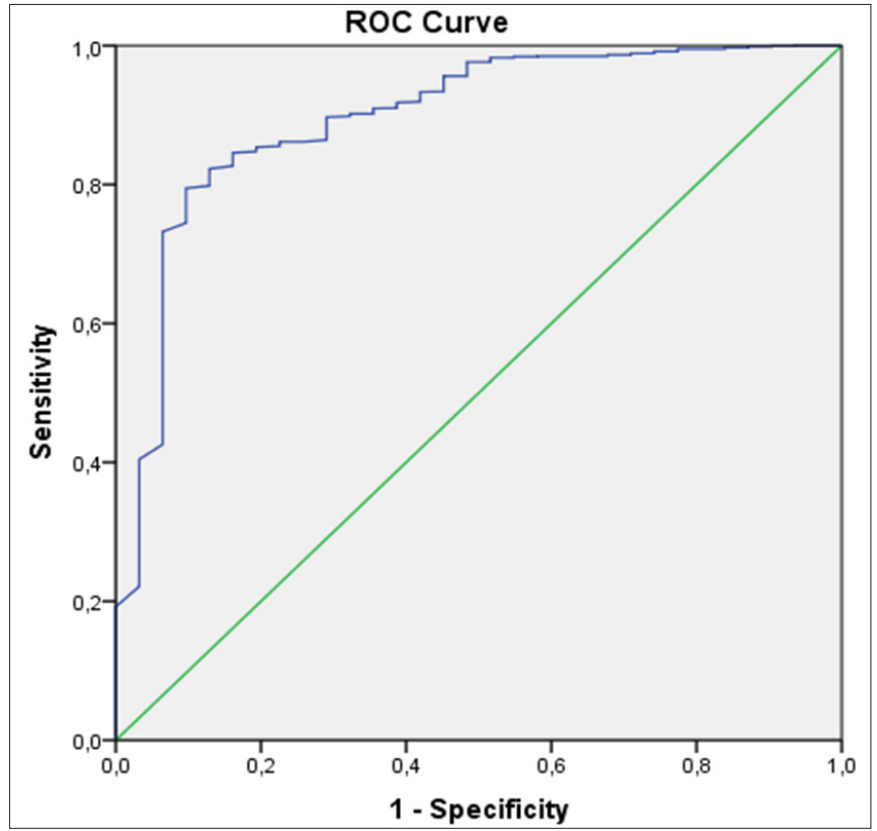

Figure 2. ROC curve for troponin variable in COVID-19 patients who died

727 patients (49.5\%) had comorbid diseases accompanying COVID-19. Hypertension was the most common comorbid disease. $27.9 \%$ of the patients were diagnosed with hypertension. $19.5 \%$ of the patient had type 2 diabetes, $9.6 \%$ had hyperlipidemia, $5.5 \%$ had asthma, 5.1\% had coronary artery disease (Table 2) (Figure 3).

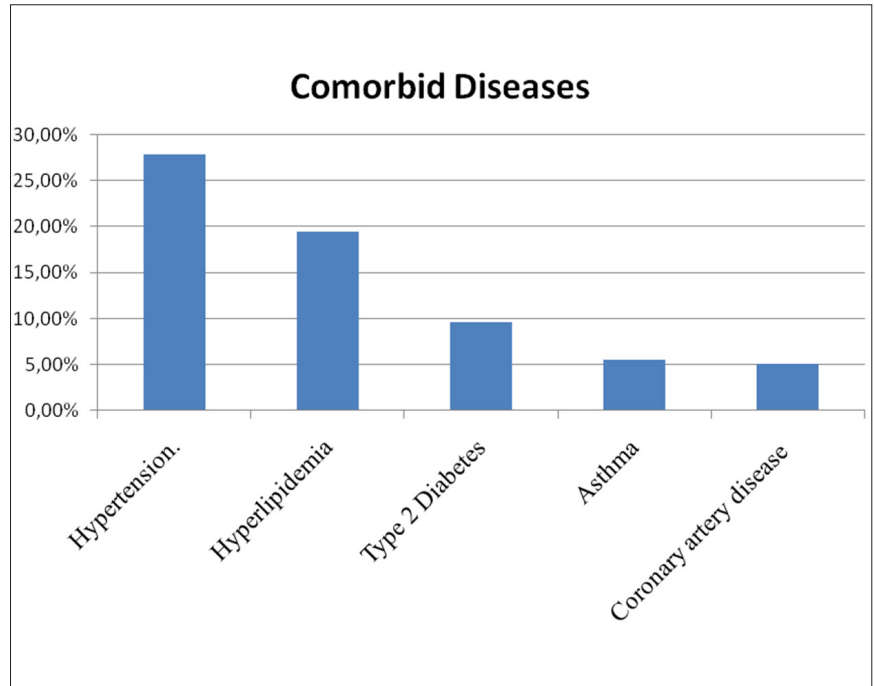

Figure 3. The most common comorbid diseases accompanying COVID-19 disease in all group

Patients with comorbid diseases accompanying COVID-19 disease had a significantly higher rate of troponin elevation $(\mathrm{p}<0.001)$ (Table 2$)$. The rate of troponin elevation was found to be significantly higher in patients with hypertension, diabetes, hyperlipidemia and coronary artery disease $(\mathrm{p}<0.001, \mathrm{p}<0.001$, $\mathrm{p}<0.001, \mathrm{p}<0.001$ ). (Table 2) No significant difference was found with troponin elevation in patients with asthma (Table 2). Troponin levels in patients with comorbid diseases accompanying COVID-19 disease were found to be significantly higher than patients without comorbid diseases $(\mathrm{p}<0.001)$ (Table 8). Also troponin levels were found to be significantly higher in the patient groups with hypertension, diabetes, hyperlipidemia and coronary artery disease $(\mathrm{p}<0.001$, $\mathrm{p}<0.001, \mathrm{p}<0.001, \mathrm{p}<0.001$ ) (Table 8). Median troponin levels were the highest in patients with coronary artery disease (Figure 4).

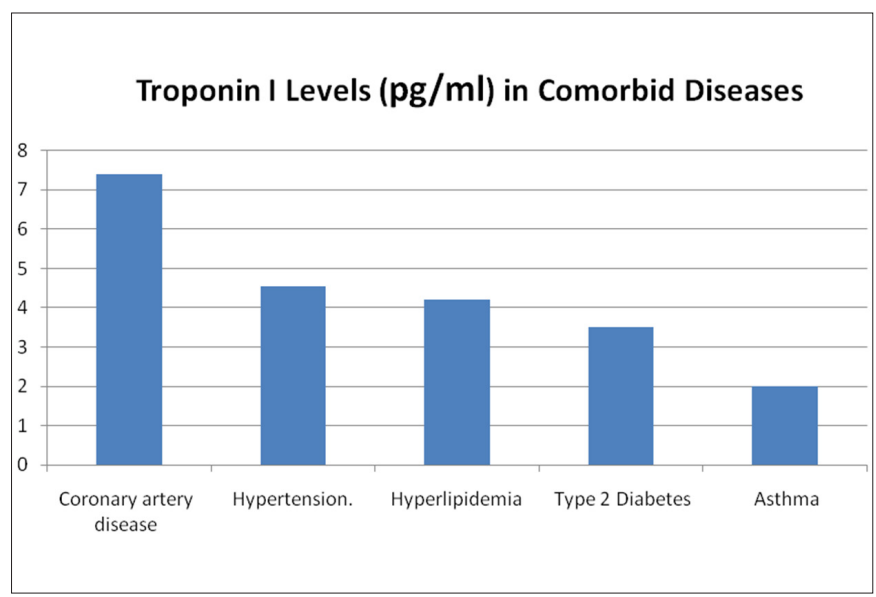

Figure 4. Median troponin levels in COVID-19 patients with comorbid disease. 


\begin{tabular}{|c|c|c|}
\hline All patients $(n=1468)$ & Troponin Level & $\mathbf{p}$ \\
\hline Gender & & $<0,001^{\mathrm{a}}$ \\
\hline Male $(\mathrm{n}=760,51.8 \%)$ & $2.90[1.80-6.00]^{\dagger}$ & \\
\hline Femalen $(\mathrm{n}=708,48.2 \%)$ & $2.20[1.20-4.70]^{\dagger}$ & \\
\hline Comorbid disease & & $<0.001^{\mathrm{a}}$ \\
\hline Yes $(\mathrm{n}=727,49.5 \%)$ & $3.50[1.90-8.40]^{\dagger}$ & \\
\hline No $(n=741,50.5 \%)$ & $2.10[1.20-3.50]^{\dagger}$ & \\
\hline Hypertension & & $<0.001^{\mathrm{a}}$ \\
\hline Yes $(n=410,27.9 \%)$ & $4.55[2.50-9.47]^{\dagger}$ & \\
\hline No $(n=1058,72.1 \%)$ & $2.10[1.30-3.82]^{\dagger}$ & \\
\hline Type 2 Diabetes & & $<0.001^{\mathrm{a}}$ \\
\hline Yes $(n=286,19.5 \%)$ & $3.50[1.90-8.82]^{\dagger}$ & \\
\hline No $(n=1182,80.5 \%)$ & $2.40[1.40-4.70]^{\dagger}$ & \\
\hline Hyperlipidemia & & $<0.001^{\mathrm{a}}$ \\
\hline Yes $(\mathrm{n}=141,9.6 \%)$ & $4.20[2.15-10.30]^{\dagger}$ & \\
\hline No $(=1327,90.4 \%)$ & $2.50[1.40-4.70]^{\dagger}$ & \\
\hline Asthma & & $0.005^{\mathrm{a}}$ \\
\hline Yes $(\mathrm{n}=81,5.5 \%)$ & $2.00[1.00-3.50]^{\dagger}$ & \\
\hline No $(n=1387,94.5 \%)$ & $2.70[1.50-5.30]^{\dagger}$ & \\
\hline Coronary artery disease & & $<0.001^{\mathrm{a}}$ \\
\hline Yes $(\mathrm{n}=75,5.1 \%)$ & $7.40[3.40-19.20]^{\dagger}$ & \\
\hline No $(n=1393,94.9 \%)$ & $2.50[1.40-4.75]^{\dagger}$ & \\
\hline Hospitalisation & & $<0.001^{\mathrm{a}}$ \\
\hline Yes $(\mathrm{n}=317,21.6 \%)$ & $1.60[0.90-2.70]^{\dagger}$ & \\
\hline No $(n=1151,78.4 \%)$ & $3.00[1.70-6.20]^{\dagger}$ & \\
\hline Pneominoa on thorax ct & & $<0.001^{\mathrm{a}}$ \\
\hline Yes $(n=1064,72.5 \%)$ & $2.80[1.70-5.90]^{\dagger}$ & \\
\hline No $(n=404,27.5 \%)$ & $2.00[1.10-3.70]^{\dagger}$ & \\
\hline Admitted to & & $<0.001^{\mathrm{a}}$ \\
\hline Ward $(\mathrm{n}=1082,73.7 \%)$ & $2.90[1.70-5.60]^{\dagger}$ & \\
\hline $\operatorname{ICU}(\mathrm{n}=69,4.7 \%)$ & $13.30[6.50-48.45]^{\dagger}$ & \\
\hline Intubation & & $0.018^{\mathrm{a}}$ \\
\hline Non-intubated $(\mathrm{n}=29,2 \%)$ & $9.00[4.35-17.50]^{\dagger}$ & \\
\hline Intubated $(\mathrm{n}=40,2.7 \%)$ & $16.45[8.22-81.12]^{\dagger}$ & \\
\hline Clinical outcome & & $<0.001^{\mathrm{a}}$ \\
\hline Healed $(\mathrm{n}=1437,97.9 \%)$ & $2.50[1.50-4.80]^{\dagger}$ & \\
\hline $\operatorname{Ex}(\mathrm{n}=31,2.1 \%)$ & $37.00[8.60-100.50]^{\dagger}$ & \\
\hline \multicolumn{3}{|c|}{ a Mann-Whitney test, ${ }^{\dagger}$ Data are presented as median (interquartile range [IQR]) } \\
\hline
\end{tabular}

\section{DISCUSSION}

Troponin elevation is a common finding in COVID-19 patients. However, the mechanism of troponin elevation in COVID-19 patients and its effect on the prognosis of the disease are not clearly known. As with other viral infections, it is possible that SARS-CoV-2 directly causes myocardial damage, but no evidence has yet been found for this. The underlying pathophysiology suggests an inflammatory response, as many COVID-19 patients have concomitant elevations in acute phase reactants such as c-reactive protein (crp) and ferritin. It may also be due to immune mechanisms as a result of cytokine increases. COVID-19 disease most frequently affects the lungs and causes pneumonia and respiratory failure. Hypoxia, hemodynamic disturbances, cardiac adrenergic overstimulation in these patients may also cause troponin elevation. It is known that thrombotic processes are activated in COVID-19 disease. The cases such as pulmonary embolism or microthrombotic disease which occurs as a result of activation of prothrombotic mechanisms can cause troponin elevation in COVID-19 patients.

In our study, we aimed to determine the frequency of troponin elevation in COVID-19 patients and to investigate the the clinical course of the patients with high troponin levels. We found the troponin level to be high in $6.7 \%$ of all COVID-19 patients. This rate was found to be higher (\%12-28) in some studies with a smaller sample size. $(9,14,15)$ Troponin elevation is seen in a considerable portion of COVID-19 patients, but its rate may vary depending on the number of patients in the study groups, the age of the patients, comorbid diseases, etc. Compared with patients with normal troponin levels, those with elevated troponin levels were older. Similar result were found in many studies.(1416) This might be due to the accompanying comorbid conditions and the fact that the heart and endothelial structure are more vulnerable with advanced age.

In present study, troponin levels were found to be higher in patients with COVID-19-associated pneumonia on thorax CT and requiring hospitalization. We found higher troponin levels in patients who required intensive care unit due to severe COVID-19. Similar results were found in some studies. In the studies of Shi S et al. (16) and Piccioni A et al. (17), troponin levels were found to be higher in patients with severe COVID-19. The mortality rate was $2.1 \%$ in the whole patient group. This rate was similar to that of the same period of the Republic of Turkey Ministry of Health data. The mortality rate was higher in the patient group with elevated troponin levels. While the mortality rate was $1 \%$ in patients with normal troponin level, the mortality rate was $17 \%$ in patients with elevated troponin level. In many studies elevated troponin levels were associated with higher mortality and the mortality rate in COVID-19 patients with elevated troponin levels has been found between 13\% and 33\%.(14-16). We found that these parameters showing the prognosis in patients with COVID-19 were worse in patients with elevated troponin level. Elevated troponin level may be an indicator of myocardial damage, immunological and thrombotic reactions resulting from pathologies caused by severe infection such as respiratory failure, hypoxia, hemodynamic disturbances, cardiac adrenergic overstimulation and cytokine storm, etc. For these reasons, cardiac troponin level may be a helpful biomarker in predicting poor prognosis in patients with COVID-19. 
We found that $49.5 \%$ of the patients had an associated comorbid disease. Hypertension was the most common comorbid disease. Troponin elevation rate and troponin levels were significantly higher in COVID-19 patients with comorbids when compared with COVID-19 patients witout comorbid disease. Median troponin levels were found to be the highest in patients with coronary artery disease among comorbid diseases. Similarly, in the study of Guo et al.(14), troponin levels were found to be higher in patients with cardiovascular disease and hypertension. This might be due to the fact that the heart and endothelium are more susceptible to inflammatory and prothrombotic mechanisms in these patients.

Based on the results of our study, troponin elevation can be considered as a marker showing poor prognosis in COVID-19 patients. We found a significant association between troponin test and conditions associated with the severity of COVID-19 disease, such as the requirement for hospital and intensive care unit admission, the presence of COVID-19-related pneumonia on thorax CT, and mortality rate. However, at present, we do not have the information to fully explain the mechanism of this. More comprehensive studies are needed on this subject.

\section{Study Limitations}

The limitations of our study are the small number of patients and the fact that it is a single center study. Multicenter and comprehensive studies involving more patients and long-term follow-up data are required.

\section{CONCLUSION}

The prognosis is worse in COVID-19 patients with high troponin test. The higher the troponin level, the worse the clinical course is. In the presence of other comorbid diseases, the troponin elevation rate and troponin level increase further. We found that troponin level has a prognostic significance in COVID-19 patients. Troponin test can be used as a predictor of prognosis as a result of evaluating the importance of troponin elevation in longterm follow-up results with more comprehensive studies in the future.

\section{ETHICAL DECLARATION}

Ethics Committee Approval: Approval was obtained from İstanbul Sancaktepe Şehit Prof. Dr. İlhan Varank Training and Research Hospital Ethics Committee (Date: 29/01/2021, Decision No: 2021/84).

Informed Consent: Because the study was designed retrospectively, no written informed consent form was obtained from patients.

Referee Evaluation Process: Externally peer-reviewed.
Conflict of Interest Statement: The authors have no conflicts of interest to declare.

Financial Disclosure: The authors declared that this study has received no financial support.

Author Contributions: All of the authors declare that they have all participated in the design, execution, and analysis of the paper and that they have approved the final version.

\section{REFERENCES}

1. Alpert JS, Thygesen K, Antman E, Bassand JP. Myocardial infarction redefined-a consensus document of the Joint European ociety of Cardiology/American College of Cardiology Committee for the Redefinition of Myocardial Infarction. J Am Coll Cardiol 2000; 36: 959-69

2. Roffi M, Patrono C, Collet J-P, et al. 2015 ESC guidelines for the management of acute coronary syndromes in patients presenting without persistent ST-segment elevation: Task Force for the management of acute coronary syndromes in patients presenting without persistent ST-segment elevation of the European Society of Cardiology (ESC). Eur Heart J 2016; 37: 267-315

3. Alcalai R, Planer D, Culhaoglu A, Osman A, Pollak A, Lotan C. Acute coronary syndrome vs nonspecific troponin elevation: clinical predictors and survival analysis. Arch Intern Med 2007; 167: 276-81

4. Wong JA, Goodman SG, Yan RT, et al. Canadian Acute Coronary Syndromes I and II, and Canadian Global Registry of Acute Coronary Events (GRACE/GRACE) Investigators. Temporal management patterns and outcomes of non-ST elevation acute coronary syndromes in patients with kidney dysfunction. Eur Heart J 2009; 30: 549-57

5. Rothan HA, Byrareddy SN. The epidemiology and pathogenesis of coronavirus disease (COVID-19) outbreak. J Autoimmun 2020; 109: 102433

6. Lai CC, Shih TP, Ko WC, Tang HJ, Hsueh PR. Severe acute respiratory syndrome coronavirus 2 (SARS-CoV-2) and coronavirus disease-2019 (COVID-19): The epidemic and the challenges. Int J Antimicrob Agents 2020; 55: 105924.

7. Poutanen SM. Etiologic agents of infectious diseases. In: Long SS, editor. Principles and practice of paediatric infectious diseases. 4th ed. 2012. p. 1547-712.

8. Pal M, Berhanu G, Desalegn C, Kandi V. Severe acute respiratory syndrome coronavirus-2 (SARS-CoV-2): an update. Cureus 2020; 12: e7423.

9. Huang C, Wang Y, Li X, et al. Clinical features of patients infected with 2019 novel coronavirus in Wuhan, China. Lancet 2020; 395: 497-506.

10. Zhang H, Penninger JM, Li Y, Zhong N, Slutsky AS. Angiotensinconverting enzyme 2 (ACE2) as a SARS-CoV-2 receptor: molecular mechanisms and potential therapeutic target. Intensive Care Med 2020; 46: 586-90 .

11. Hamming I, Timens W, Bulthuis ML, Lely AT, Navis G, van Goor $\mathrm{H}$. Tissue distribution of ACE2 protein, the functional receptor for SARS coronavirus. A first step in understanding SARS pathogenesis. J Pathol 2004; 203: 631-7.

12. Alhogbani T. Acute myocarditis associated with novel Middle East respiratory syndrome coronavirus. Ann. Saudi Med 2016; 36: $78-80$.

13. Oudit GY, Kassiri Z, Jiang C, et al. SARS-coronavirus modulation of myocardial ACE2 expression and inflammation in patients with SARS. Eur. J. Clin. Investig 2009; 39: 618-25. 
14. Guo T, Fan Y, Chen M, et al. Cardiovascular implications of fatal outcomes of patients with coronavirus disease 2019 (COVID-19). JAMA cardiol 2020; 5: 811-8.

15. Zhou F, Yu T, Du R, et al. Clinical course and risk factors for mortality of adult inpatients with COVID-19 in Wuhan, China: a retrospective cohort study. Lancet (London, England) 2020; 395: 1054-62.

16. Shi S, Qin M, Shen, B, et al. Association of cardiac injury with mortality in hospitalized patients with COVID-19 in Wuhan, China. JAMA Cardio 2020; e200950.

17. Piccioni A, Brigida M, Loria V, et al. Role of troponin in COVID-19 pandemic: a review of literature. Eur Rev Med Pharmacol Sci 2020; 24: 10293-300. 